\title{
Hand in hand: rethinking anatomical votives as material things
}

\begin{abstract}
Religious experience in ancient Italy was intimately connected with the production, manipulation, veneration, and discarding of material objects. This chapter argues that for a fuller understanding of lived religion it is necessary to approach these objects as more than the mere material or visual expression of otherwise intangible concepts. It consequently explores the affective relations between things, particularly how objects and human bodies assemble in order to produce lived religious experience and religious knowledge. Taking votive terracotta models of hands from mid-Republican Italy as a case study, this chapter adopts a broadly new materialist approach to the examination of anatomical votives, focusing on the tripartite affectivity of these offerings as objects manipulated in the moment of ritual, as material things, and as bodily proxies.
\end{abstract}

\section{Introduction}

Religious experience in ancient Italy was intimately connected with the production, manipulation, veneration, and discarding of material objects. Today, these objects are often used to identify and reconstruct past forms of ritual activity: ceramic vessels indicate the pouring of libations or giving of food offerings, altars suggest the celebration of sacrifice, and inscriptions record the roles of cult attendants. They also prompt speculation about the ideas, beliefs, and expectations expressed in ritual performance: votive offerings attest to the potential for divine intervention, cult statues to the existence of a deity with specific attributes. However, although the material culture of religion offers evidence for the performance of ritual activities and the concepts with which these were connected, for a fuller understanding of lived religion it is necessary to approach these objects as more than the mere material or visual expression of otherwise intangible concepts or transitory performances. After all, there is more to objects than meets the eye. Objects are, in fact, integral to

\footnotetext{
Acknowledgment: I would like to thank the members of the LAR project for inviting me to contribute to the conference in Eisenach and this volume. I am also grateful to Jessica Hughes and Katharina Rieger for their comments on earlier drafts, which both challenged and helped me to refine my arguments. Any remaining faults are my own.
}

Ә Open Access. (C) 2020 Emma-Jayne Graham, published by De Gruyter. (c) BY-NC-ND This work is licensed under a Creative Commons Attribution-NonCommercial-NoDerivatives 4.0 International License.

https://doi.org/10.1515/9783110557596-012 
the ways in which humans inhabit and experience a dwelt-in world, forcing them "to reconsider who they are and how they relate to the rest of the world" (Harris and Cipolla 2017, 92). This is something that researchers sometimes choose to comprehend with reference to a particular theoretical standpoint, such as the symmetry of Actor-Network Theory (Latour 2005), the entanglement of people and objects in relationships of dependence and dependency (Hodder 2012), or the reframing of objects as "things" (Olsen 2010). Especially pertinent for the study of lived ancient religion is the recognition that material objects neither "stand as vehicles of cultural meanings, waiting to be decoded and to yield their singular sense" (Joyce 2008, 26), nor "sit in silence waiting to be embodied with socially constituted meanings" (Olsen 2010, 10). Indeed, as recent scholarship has demonstrated, rather than pre-existing as an abstract idea awaiting material expression, understandings of being in the world that concern religion - that is, lived religious knowledge - are actively produced and renegotiated situationally, via the bodily performance of ritual acts and engagement with materials. ${ }^{1}$ Calls have increasingly been made for researchers to explore more closely the ways in which objects and humans entangle in order to produce lived experience, more specifically to go further than just thinking about what objects are made to do as part of religious activities, to consider what they are and why that matters. This aligns more broadly with the so-called new materialist approach of archaeological theory, which involves looking beyond questions of materiality - usually defined as the study of how objects "are actively used in social practices" (Mills and Walker 2008, 14), or how the physical world "is appropriated in human projects" (Ingold 2012, 439) - in order to attend instead to the materialness of objects themselves (Ingold 2007; 2012). This means paying attention to their very physicality as material "things", including their "emotive or sensory qualities" or affordances (Pollard 2008, 48). ${ }^{2}$ It also means recognizing the agency that results when objects combine, sometimes only temporarily, with other things, including human bodies, minds, beliefs and ideas, as well as more-than-human things such as plants, animals, and gods, in a set of relations referred to by many new materialist scholars as an "assemblage” (Harris and Cipolla 2017, 139).

1 For example: Chidester 2005; Boivin 2009; Morgan 2010a; 2010b; Frankfurter 2017; Graham 2017a.

2 Knappett $(2004,44)$ notes that James Gibson first conceived of affordances as "The potentialities held by an object for a particular set of actions." "Things" are defined and discussed in section 6 below. 
Accordingly, an assemblage can be defined as "a specific arrangement of diverse, heterogeneous, interacting components that has specific effects; an assemblage acts, and acts in a way that none of its components can without being in such a configuration" (Fowler 2017, 96 original emphasis). ${ }^{3}$ Studying assemblages therefore means studying the affective relations between things, including human bodies and objects.

This chapter uses votive terracotta models of hands from mid-Republican Italy (approximately late 4th to early 1st century BCE) as a case study through which to explore the consequences for lived ancient religion of these more nuanced approaches to objects, particularly their inclusion, alongside the human body, within particular types of assemblage. It contends that a more critical appraisal of the feedback loop between bodies and objects in the course of the performance of ritual activities can help to make sense of the ways in which objects, combined with bodily motion, sensory perception, temporality, and spatiality, acted as "instruments of knowledge" (Chidester 2005, 57), in this case instruments of religious knowledge. More specifically, the argument outlined here demonstrates that in order to understand the capacity of objects, such as anatomical votives, to generate forms of knowledge that extend beyond the representational, studies of the bodily manipulation of material objects by actors in ritual performance contexts must be combined with an appreciation of the affordances of the materials from which objects were made, and the forms that this material was shaped into. This is what Oliver Harris and Craig Cipolla (2017, 200), amongst others, describe as approaching the past via a non-hierarchical flat ontology, a theory of being in which humans "take up their place as one kind of entity among many others." ${ }^{4}$ Anatomical offerings provide a particularly interesting perspective on this because of the ways in which they complicate these relationships by mimicking the human body itself. This chapter consequently adopts a broadly new materialist approach to the examination of anatomical votives, exploring for the first time the tripartite affectivity of these offerings as objects manipulated in the moment of ritual, as material things, and as bodily proxies.

3 This definition of "assemblage" is used throughout this chapter, except when the word is used in a more conventional sense to refer to a collection of artifacts excavated from a given site or context (e.g. an assemblage of deposited artifacts). Hamilakis (2013, 126-128) has written specifically about "sensorial assemblages", but all assemblages are ultimately sensorial in nature since their components have variable affective capacities. For discussion of assemblage theory within new materialist archaeology, see Crellin 2017; Hamilakis and Meirion Jones 2017. 4 For further discussion of flat ontologies see Garcia-Rovira 2015. 


\section{Religious knowledge and objects}

This chapter, then, takes its lead from recent work in the cross-disciplinary field of material religion, which has stressed that objects actively participate in the performance of ritual activities and the production of religious knowledge. ${ }^{5}$ From this standpoint, the significance of objects lies not only in the forms that humans shape materials into, but also the ways in which those materials become enmeshed with the bodies of ritual practitioners, principally via the senses, affecting or stimulating emotions, movements and, ultimately, understandings or forms of knowledge. David Morgan (2010a, 8) refers to this combination of bodies and objects in motion as "the felt-life" of religion. In turn, David Chidester (2005) and Nicole Boivin (2009) have established that religious knowledge extends beyond the verbal and somatic expression of ideas, as well as beyond the embedding in objects of pre-existing beliefs. As Boivin (2009, 274) explains, "ideas and cultural understandings do not precede, but rather are helped into becoming by, the material world and human engagement with it during the course of ritual activity. Human thought and experience has not only used the world as a prop for expressing itself, but has, in fact, often been enabled by that world." Consequently, religion can be studied not just as a set of doctrines or shared ideas, but as a form of embodied knowledge which is both produced and "felt" through the lived performance of activities and movements that encompass both the human body and the rest of the material world. The term "religious knowledge" is henceforth used in this chapter to denote a particular understanding of the world that is rooted in a person's body, produced by their body, and lived by their body, specifically during the course of religious activities. It is therefore a form of proximal knowing that is produced in the very moment of each bodily and sensory experience. This knowledge is subtly different from, but might be related to, broader forms of distal religious knowledge or, in other words, knowledge of the bigger picture of a community's religious practices and how one's own lived activities align with shared cultural expectations about the divine world. As this chapter will argue, proximal religious knowledge is generated by personal lived experience: the experience of dedicating a terracotta votive offering in the form of a hand, for example, produced a form of proximal religious knowledge that was a direct consequence of that object's material qualities (discussed below), combined with the sensing body of the dedicant, the motivations or emotional circumstances under which they performed that activity, and their spatio-temporal

5 In particular this includes Boivin 2009; Morgan 2009; 2010a; 2010b; Frankfurter 2017. 
setting. This knowledge was subtly different from that produced when a person dedicated a terracotta swaddled infant, or a bronze figurine of Hercules, because even though the actions performed by all practitioners respected culturallyestablished (distal) patterns of ritual behavior and ideas (i.e. that a thank-offering was appropriate after the completion of a vow; that the divine could intercede in the fortunes or well-being of mortals), their lived experience resulted from a subtly different assemblage of things. In these examples, this was an assemblage composed of objects with different material qualities, as well as different bodies, motivations, and emotions. Where it appears in this chapter, then, the word "knowledge" should therefore not be read as a synonym for "thinking", nor for the idea of "belief", but of "knowing in one's body". ${ }^{6}$ As Meredith McGuire (2008, 100 and 102) affirms: "the practices for engaging in ritual are embodied - embedded in the participants' mind-body as a unity," whilst "bodily sensations produce a confirmation that what one is experiencing is real, not just imaginary."

Because it is grounded in the dynamic personal "felt-life", or lived practice of each individual, proximal religious knowledge may therefore not be as easily communicable as distal forms of knowledge, which are based on doctrines or shared customs or beliefs. For this reason it is distal forms of knowledge that tend to be reproduced by ancient written sources and modern accounts of "Roman religion" alike, meaning that the significance of proximal or personal religious knowledge is often overlooked in studies of ancient religious practice. Furthermore, until now, investigations of the relationship between bodies, objects, and religious knowledge have tended to see this as a simple coming together of the human body with objects that were significant purely because of how humans interpreted their form or shape, with their specific material properties remaining largely unnoticed (for exceptions see Rieger 2016; Graham 2017a). The significance of objects within many existing approaches to ancient religion therefore inclines towards an acknowledgement of their ostensibly passive presence at ritual performances. ${ }^{7}$ This chapter, in contrast, proposes that a more critical examination of the materialness of objects in this case dedicated objects - can re-materialize approaches to ancient lived religious knowledge in significant new ways.

6 Bodily knowing is regularly linked to the senses, with studies often emphasizing aspects of the sensorium that promote particularly proximal forms of engagement with the world, including taste and touch, in contrast to visual and aural forms of perception which maintain a distance between world and body. For more on proximal and distal forms of knowledge see Cooper and Law 1995, and specifically in relation to touch, see Bailey 2014, 33-35.

7 This is exemplified by the statement that "objects were the primary material which created a physical and visual framework around which religious life unfolded in antiquity" (Raja and Weiss 2016, 298, emphasis added). 


\section{Anatomical votives as meaningful objects}

Anatomical models are almost ubiquitous within deposits of objects dedicated at sites used for the celebration of votive cult in mid-Republican Italy. Dated to a period between the late 4th and 2nd/early 1st century BCE, but with clear antecedents in the bronze figurative models of heroes and deities, as well as terracotta human heads, known from earlier periods, anatomical votives are traditionally associated with the custom of petitioning and then thanking the divine for intervention in the health and well-being of the dedicant (Turfa 1994; Recke 2013; Graham and Draycott 2017). Thus, models in the shape of eyes are commonly connected with the healing of visual impairments, feet with injuries and mobility impairments, and wombs with conception, pregnancy, or childbirth. Nevertheless, evaluations of the form of these objects need not be restricted to medical diagnoses: eyes might reference mysteric vision and enlightenment (Petridou 2017), or provide acknowledgement that a deity was "watching over" someone; feet might be connected to pilgrimage, travel, or the idea of metaphorical movement from one state of being to another (Graham 2017b; Graham (forthcoming)); wombs might be representative of the fertile future of a newly married couple, or an attempt to express in material form a complex combination of "folk tradition" and medical concepts of the "wandering womb" (Flemming 2017). Increasingly, scholarship on anatomical votives seeks to explore the abundance of meanings ascribed to these models of the fragmented body, including the extent to which dedicants considered that they were surrendering an actual part of their own body in terracotta form (Hughes 2008; 2017a; papers in Draycott and Graham 2017). Their intent is to delve deeper into the ways in which votive offerings could be multivalent artifacts with highly personal situational relevance, whilst not overlooking their universal role at the heart of a broadly homogeneous practice of making a vow, followed by an acknowledgement of its perceived resolution (Graham and Draycott 2017, 7-8).

However, even the most vigorous acknowledgement that votive objects adopted a contextually-specific resonance dependent upon the needs, experiences, identities, and motives of the persons who chose to dedicate them, continues to emphasize the representational role of objects in religious practice. Following this line of reasoning, a model of a foot might mean different things to different petitioners but must, at the very least, represent a concern that can be connected with a range of shared ideas for which a foot can serve as a suitable indicator. From this perspective we might imagine a votive manufacturer's workshop, its shelves lined with mold-made limbs, ears, eyes, internal organs, torsos, and heads, all waiting for a petitioner to select one and bestow upon it one of many possible meanings in relation to their personal circumstances (e.g. a sore foot). 
A second customer might select an object with the same form, but ascribe to it a different meaning (e.g. an act of pilgrimage). Both dedicants imbued their own discrete objects with a singular meaning, which, upon the excavation of those two identical artifacts several millennia later, archaeologists can then speculate about as part of a spectrum of multivalence that is based on a predetermined range of potential symbolic meanings. In this approach, the object as a material entity (i.e. its fabric, color, dimensions, texture, surface temperature, weight, and so on) has no relevance beyond the shape that it takes - it looks like a foot - and the location in which it was found - most likely in a pit associated with a sanctuary. Together these identify it as a votive offering and provide the impetus for an interpretation of the varied petitions with which it might be connected. Its reality as a material entity is important merely in that it signals to both petitioner and excavator the existence of an otherwise intangible or immaterial idea or action.

Attentiveness to multivalence is extremely valuable for moving closer to an appreciation of the complexities of votive offerings as individual objects connected with lived religion, and remains a necessary and important aspect of understanding the agency of the artifacts that lie at the heart of this paper. However, labelling an anatomical votive purely in relation to what it signifies, whilst neglecting to consider its connotations as a material entity, leaves us at least one step removed from really understanding what objects actively brought to the performance of the ritual act of votive dedication. In other words, in remaining focused on what an object might stand for, rather than what it actually is, we lose all sense of the object itself. These tensions are revealed particularly well by the objects which serve as this chapter's case study: votive hands.

\section{Votive hands in mid-Republican Italy}

Studies of these anatomical models are hampered by the absence of any comprehensive survey of votive hands (and/or upper limbs) at Italian sites, but their typical characteristics and an impression of their distribution can be established. Votive hands were sometimes produced in bronze, although the few known examples originate predominantly from northern regions of Italy: Annamaria Comella (1981) records the presence of only two hands in the Veneto/Cispadana region, both of which were bronze, with additional bronze "arti superiori" at two sites in the interior of northern Etruria. Hands/upper limbs were more commonly fabricated from clay pressed into molds, and are one of the typical features of the so-called Etrusco-Latial-Campanian votive tradition. The isolated hand is usually modelled in its open form, displaying the palm, heel and the back of the hand 
from fingertips to wrist, with the fingers together and extended, but might also be fashioned to include the forearm and, in some instances, the entire arm (Figs. 1 and 2). ${ }^{8}$ They appear as single, individual pieces rather than pairs, with published deposits indicating that both left and right sides of the body were represented, although the nature of the available data makes it impossible to draw conclusions about handedness. Hands/upper limbs take a range of lifesized, under life-sized and sometimes miniaturized forms.

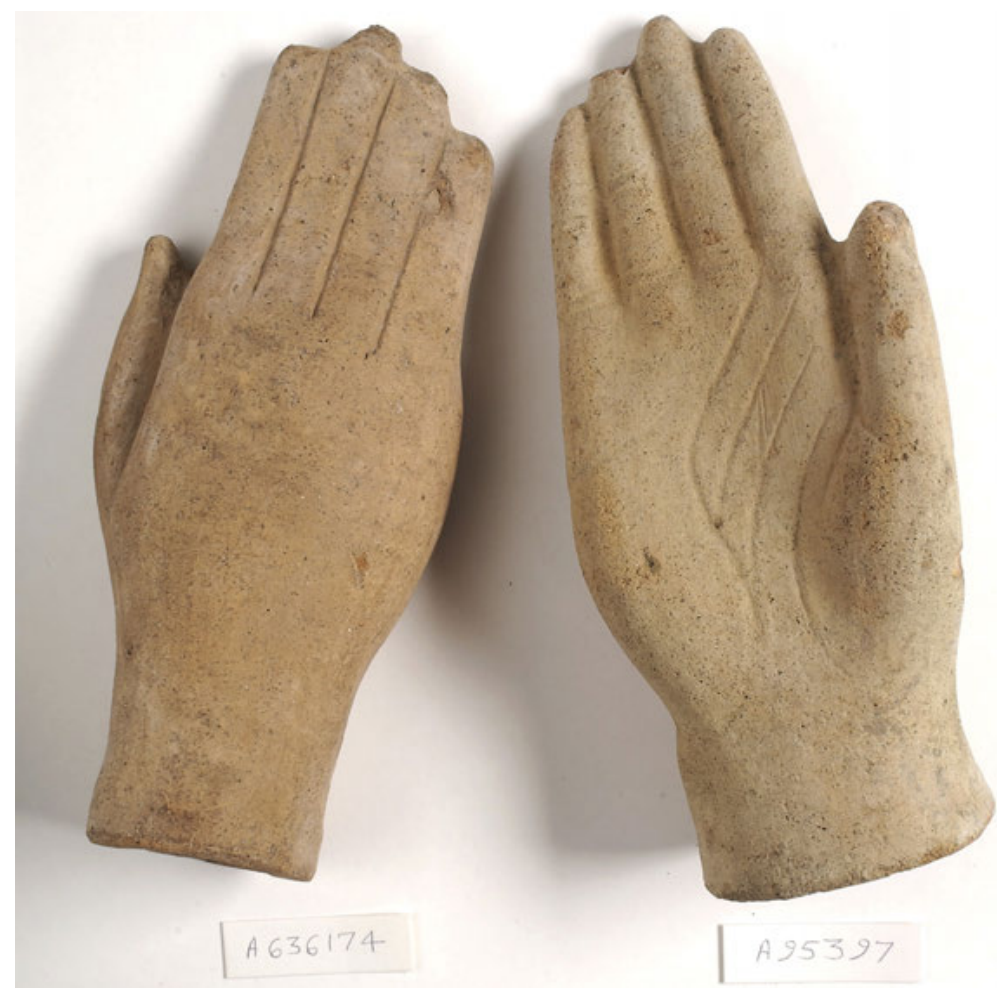

Fig. 1: Terracotta votive hands of unknown provenance (Wellcome Library, London, Museum nos. A636174 and A95397). Reproduced under CC BY 4.0 License.

Maria Fenelli (1975) collated information concerning anatomical votives from 150 individual votive assemblages from 96 locations across Italy. Of the individual

8 Broad surveys and brief excavation reports do not regularly distinguish between hands and upper limbs, nor is it always clear whether fragmentary hands originally belonged to a larger object, such as a statue. 


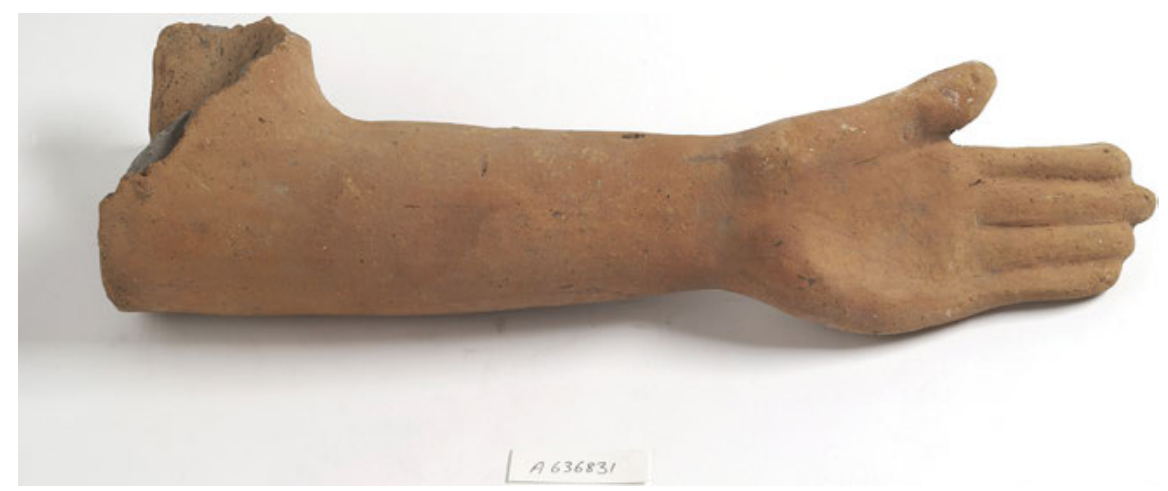

Fig. 2: Terracotta votive forearm and hand of unknown provenance (Wellcome Library, London, Museum no. A636831). Reproduced under CC BY 4.0 License.

sites and collections that she surveyed, 69 (46\%) featured at least one example of a hand, and 33 (22\%) returned at least one example of either a forearm or an arm. These figures should undoubtedly be revised upwards as a consequence of more recently discovered deposits. Indeed, Annamaria Comella (1981) completed her own survey of 228 votive assemblages across Italy, 123 (54.8\%) of which featured anatomical votives. Amongst the latter she recorded the presence of 86 with hands and/or upper limbs. No comparable study has since been produced, but even a decade ago estimates of the total number of sites with anatomical votives were ranging up to 290 (Glinister 2006, 13 n.11). Despite these uncertainties, Comella's data provides a baseline from which to develop an understanding of how widespread these types of offering were, both geographically and in relation to other popular types (Tab. 1 and Fig. 3).

Models of hands/upper limbs are known throughout Italy (with the exception, in 1981, of coastal northern Etruria, the territory of the Marsii, and Samnium), and like all anatomical votives they demonstrate a particular concentration in the region of Latium (41 out of 52 anatomical votive assemblages: $78.9 \%$ ) and the territories collectively referred to in modern scholarship as Etruria (27 out of 43 anatomical votive assemblages: $62.8 \%$ ). Hands/upper limbs are therefore known from at least $68.8 \%$ of anatomical votive assemblages across Italy. This frequency is slightly lower than that for feet/lower limbs ( $80 \%)$, although the latter demonstrate a similar overall pattern in relation to levels of density in Latium (47 out of 52 anatomical votive assemblages: 90.4\%) and Etruria (31 out of 43 anatomical votive assemblages: $72.1 \%$ ).

Excavation reports and publications supply more detail concerning individual sites within these regions, and a brief survey of the largest and best-studied 
Tab. 1: Votive assemblages in Italy (based on Comella 1981). Shaded rows represent regions within Etruria.

\begin{tabular}{|c|c|c|c|c|c|}
\hline Region & $\begin{array}{r}\text { Total no. } \\
\text { assemblages }\end{array}$ & $\begin{array}{r}\text { Total AV } \\
\text { assemblages }\end{array}$ & $\begin{array}{r}\mathrm{AV} \\
\text { assemblages (\%) }\end{array}$ & $\begin{array}{r}\text { AV } \\
\text { assemblages } \\
\text { with upper } \\
\text { limbs }\end{array}$ & $\begin{array}{r}\text { AV } \\
\text { assemblages } \\
\text { with upper } \\
\text { limbs (\%) }\end{array}$ \\
\hline $\begin{array}{l}\text { Venetia/ } \\
\text { Cispadana }\end{array}$ & 8 & 2 & $25 \%$ & 2 & $100 \%$ \\
\hline Picenum & 3 & 3 & $100 \%$ & 2 & $66.6 \%$ \\
\hline Umbria & 8 & 2 & $25 \%$ & 1 & $50 \%$ \\
\hline $\begin{array}{l}\text { Northern } \\
\text { Etruria } \\
\text { (interior) }\end{array}$ & 8 & 4 & $50 \%$ & 2 & $50 \%$ \\
\hline $\begin{array}{l}\text { Northern } \\
\text { Etruria } \\
\text { (coastal) }\end{array}$ & 5 & 2 & $40 \%$ & 0 & $0 \%$ \\
\hline $\begin{array}{l}\text { Vulcenate } \\
\text { territory }\end{array}$ & 15 & 10 & $66.6 \%$ & 7 & $70 \%$ \\
\hline $\begin{array}{l}\text { Volsinian } \\
\text { territory }\end{array}$ & 5 & 4 & $80 \%$ & 1 & $25 \%$ \\
\hline $\begin{array}{l}\text { Tarquinian } \\
\text { territory }\end{array}$ & 9 & 8 & $88.8 \%$ & 7 & $87.5 \%$ \\
\hline $\begin{array}{l}\text { Caeretan } \\
\text { territory }\end{array}$ & 14 & 10 & $71.4 \%$ & 5 & $50 \%$ \\
\hline $\begin{array}{l}\text { Veiian } \\
\text { territory }\end{array}$ & 8 & 5 & $62.5 \%$ & 5 & $100 \%$ \\
\hline $\begin{array}{l}\text { Faliscan- } \\
\text { Capenate } \\
\text { territory }\end{array}$ & 9 & 5 & $55.5 \%$ & 4 & $80 \%$ \\
\hline Latium & 82 & 52 & $63.4 \%$ & 41 & $78.8 \%$ \\
\hline $\begin{array}{l}\text { Sabine } \\
\text { territory }\end{array}$ & 1 & 1 & $100 \%$ & 1 & $100 \%$ \\
\hline $\begin{array}{l}\text { Aequian } \\
\text { territory }\end{array}$ & 6 & 3 & $50 \%$ & 2 & $66.6 \%$ \\
\hline $\begin{array}{l}\text { Marsian } \\
\text { territory }\end{array}$ & 1 & 0 & $0 \%$ & 0 & $0 \%$ \\
\hline
\end{tabular}


Tab. 1 (continued)

\begin{tabular}{lrrrrr}
\hline Region & $\begin{array}{r}\text { Total no. } \\
\text { assemblages }\end{array}$ & $\begin{array}{r}\text { Total AV } \\
\text { assemblages }\end{array}$ & $\begin{array}{r}\text { AV } \\
\text { assemblages (\%) }\end{array}$ & $\begin{array}{r}\text { AV } \\
\text { assemblages } \\
\text { with upper } \\
\text { limbs }\end{array}$ & $\begin{array}{r}\text { assemblages } \\
\text { with upper } \\
\text { limbs (\%) }\end{array}$ \\
\hline Samnium & 12 & 5 & $41.7 \%$ & 0 & $0 \%$ \\
\hline Campania & 9 & 5 & $55.5 \%$ & 4 & $80 \%$ \\
\hline $\begin{array}{l}\text { Southern } \\
\text { Italy }\end{array}$ & 19 & 3 & $15.8 \%$ & 1 & $33.3 \%$ \\
\hline Sicily & 6 & 1 & $16.7 \%$ & 1 & $100 \%$ \\
\hline TOTAL & 228 & 125 & $54.8 \%$ & 86 & $68.8 \%$ \\
\hline
\end{tabular}

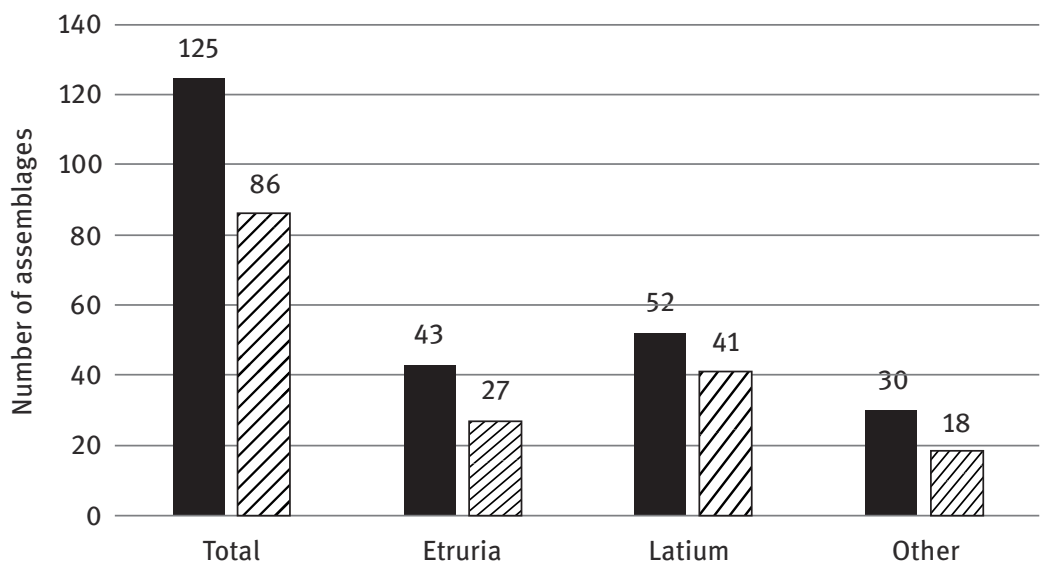

Number of $A V$ assemblages $\square$ Number of AV assemblages with upper limbs

Fig. 3: Number of anatomical votive (AV) assemblages and those featuring upper limbs from the whole of Italy and from each (combined) region (based on Comella 1981).

provides a useful impressionistic view of raw numbers (summarized in Tab. 2). For instance, at Ponte di Nona (Latium) feet were dominant (38.2\%), but the second largest group of offerings identified were hands (17.3\%) (Potter 1989). A similarly high proportion of lower and upper limbs was recovered at Fregellae (Latium): feet/lower limbs make up $69.7 \%$ of the anatomical votive assemblage, but hands/ upper limbs again comprise the second most numerically significant groups 
Tab. 2: Total number of anatomical votives and upper/lower limb types at sites mentioned in the text.

\begin{tabular}{lrrrrr}
\hline Location & Total AVs & Hands & Upper limbs & Feet & Lower limbs \\
\hline Ara della Regina, Tarquinia (Etruria) & 759 & - & 46 & 225 & 26 \\
\hline Communità, Veii (Etruria) & 407 & 13 & 45 & 41 & 190 \\
\hline Fregellae (Latium) & 3367 & 292 & 266 & 1654 & 693 \\
\hline Pantanacci (Latium) & $c .490$ & $c .10$ & $c .10$ & $c .30$ & c.20 \\
\hline Ponte di Nona (Latium) & 6171 & 1066 & - & 2368 & - \\
\hline
\end{tabular}

(totaling 16.6\%), with the next largest comprising masks $(169=5 \%)$ and phalli $(106=3.2 \%)$ (Ferrea and Pinna 1986). Although individual numbers differ, these patterns are comparable with those at other sites. In Etruria, at the monumental Ara della Regina temple at Tarquinia, 46 upper limbs $(6.1 \%)$ were reported, compared with 26 legs (3.4\%) and 225 feet (29.7\%) (Comella 1982), and in the Communità deposit at Veii, hands (3.2\%) and upper limbs (11.1\%) were found alongside feet (10.1\%) and lower limbs (46.7\%) (Bartoloni and Benedettini 2011). At other sites, neither upper nor lower limbs stand out as particularly numerous, including the recent discovery of a deposit of approximately 490 anatomical offerings in a cave at Pantanacci, Lanuvium. Here, early indications suggest that around $4.1 \%$ of the offerings are upper limbs and $10.2 \%$ are lower limbs, comparable with more numerous uteri (c. 17\%) and an unusual collection of oral cavities (c. 8\%) (Attenni and Ghini 2014). ${ }^{9}$ Feet/lower limbs outnumber hands/upper limbs at this selection of sites from the central Italian regions, but it is evident that in many cases models of hands were dedicated in significant numbers.

\section{Interpreting votive hands}

Interpretations of votive hands remain conservative. As with the majority of anatomical votives, an absence of evidence for pathologies has not prevented studies aligning them specifically with requests for healing, especially

9 Attenni $(2017,29)$ reports a total of at least 1500 terracotta votives, but only 1020 of all of the objects from the cave, including both ceramic vessels and terracotta votives, have been studied at the time of writing. 
for conditions associated with agricultural lifestyles (Potter 1989). Their occurrence in votive deposits alongside large quantities of feet/lower limbs may support this interpretation, although other scholars have suggested that both types might be "expressions of willingness to devote one's actions, travels, and so on to the god, rather than emblems of specific diseases" (Turfa 1994, 224), whilst others have noted that hands might "express the prayer of the dedicant" (Recke 2013, 1076). Given the multivalent potential of votive offerings, it is possible that petitioners dedicated hands for many reasons, some of which are outlined in Tab. 3.

Tab. 3: Ways in which votive hands might be interpreted and broadly categorized in relation to types of request or other activities.

\begin{tabular}{|c|c|c|}
\hline An indicator of & Interpretation & Category \\
\hline Injury/acute conditions & $\begin{array}{l}\text { A range of potential conditions, e.g. blisters, } \\
\text { burns, crushing, dermatitis, fractures, laceration, } \\
\text { tendon tears }\end{array}$ & Healing \\
\hline $\begin{array}{l}\text { Chronic/degenerative } \\
\text { conditions }\end{array}$ & $\begin{array}{l}\text { A range of potential conditions, e.g. carpal tunnel } \\
\text { syndrome, osteoarthritis, psoriasis, rheumatoid } \\
\text { arthritis, tendonitis }\end{array}$ & Healing \\
\hline Other medical conditions & $\begin{array}{l}\text { A range of potential conditions, e.g. cancer, } \\
\text { multiple sclerosis, Parkinson's }\end{array}$ & Healing \\
\hline Manumission & $\begin{array}{l}\text { "Going out from the hand", connected with being } \\
\text { freed or the freeing of others }\end{array}$ & Life course \\
\hline Marriage & $\begin{array}{l}\text { Representative of the dextrarum iunctio, the } \\
\text { clasping of right hands as a common Roman motif } \\
\text { for marriage }\end{array}$ & Life course \\
\hline $\begin{array}{l}\text { Contract: commercial, } \\
\text { business or political }\end{array}$ & $\begin{array}{l}\text { Representative of dextrarum iunctio as indicative } \\
\text { of concord between persons }\end{array}$ & Conceptual \\
\hline $\begin{array}{l}\text { Contract: with the divine, } \\
\text { a vow }\end{array}$ & $\begin{array}{l}\text { Representative of dextrarum iunctio as indicative } \\
\text { of concord between human and divine established } \\
\text { by a vow }\end{array}$ & $\begin{array}{l}\text { Conceptual } \\
\text { or Ritual }\end{array}$ \\
\hline Oath & $\begin{array}{l}\text { Representative of raised hands in oath swearing, } \\
\text { marking initial vow as a solemn occasion/ } \\
\text { acknowledgement that oath had been upheld }\end{array}$ & $\begin{array}{l}\text { Conceptual } \\
\text { or Ritual }\end{array}$ \\
\hline Prayer & Representation of raising of hands in act of prayer & Ritual \\
\hline Embodied act of offering & $\begin{array}{l}\text { The role of the hand in the act of making an } \\
\text { offering; gesture of handing something over }\end{array}$ & Ritual \\
\hline
\end{tabular}


Nevertheless, by adopting a flat ontological standpoint, in which these votive offerings are considered to be an equal part of a relational assemblage that featured not only human minds but also human bodies, we must look beyond the predominantly representational interpretations in Tab. 3 in order to avoid what Lambros Malafouris (2013, 90-91) terms "the fallacy of the linguistic sign". After all, in the case of votive hands, this assemblage was deeply stratified, since these objects replicated, perhaps were even a direct proxy for, the same living body part that manipulated them. They also concurrently provided a mechanism through which the material of the object could act back on the body through the sense of touch (Bailey 2014, 34). Therefore, the hand of the dedicant not only manipulated an object, but an object which possessed its own capacity to affect the living body that grasped it, whilst it also resembled its form. Indeed, according to Maurice Merleau-Ponty $(1968,133)$ human bodies grasp and affect the world via things, although they do so "only if my hand, while it is felt from within, is also accessible from without, itself tangible ... if it takes its place among the things it touches, is in a sense one of them." For Merleau-Ponty and others, the significance of objects is to be found in what he termed their "flesh", in other words the fact that all objects, plants, animals, and humans not only share certain material properties which are inherent to their existence as physical forms, but also share "membership in a dwelt-in world" in which they all have "the capacity for making a difference to the world and to other beings" (Olsen 2010, 9 original emphasis). Merleau-Ponty's description of his own hand in relation to "the things it touches," and its own reciprocal tangibility, spotlights the role of sensory perception in understanding the relations between human bodies and other materials within an assemblage (Chidester 2005; Graham 2017a). Bodies, via hands, grasp and manipulate objects but, through the senses, the materialness of objects also acts to affect and manipulate the grasping body itself, their qualities (e.g. weight, temperature, texture, smell, and form) determining how they are perceived and how the relations between them are produced and consequently understood. Together, and as part of a wider assemblage that also includes the temporal, spatial, and epistemological context in which that action takes place, body and object work to produce a unique lived experience. Merleau-Ponty may not have had anatomical votives in mind, but his observations are particularly resonant when the possibility arises that the objects one's hands touch, and are touched by, might be alternative types of hand. Votive hands, then, offer a complex but potentially illuminating context in which to investigate the role of the materialness of objects and bodies in the ancient production of religious forms of knowledge. 


\section{Votive hands as things}

The most recent and influential studies of objects have focused, however, on an almost entirely practical or mundane material world, rather than material entities implicated in, or made specifically for use in ritual. ${ }^{10}$ Theoretical focus rests, therefore, on the types of material entities that humans depend upon to make things happen as part of a hypothetical everyday life in which religion - lived or otherwise - generally plays no part. As a result, objects are frequently approached as entities that can be assigned a single, culturally agreed upon function, e.g. jugs hold and pour liquids. To fully understand how an assemblage of objects and bodies produced religious knowledge, however, this basic principle must be questioned. After all, a jug can hold and pour liquids in any context, but the difference that it makes to the world varies, depending upon the nuances of both cultural and performative context, such as whether it is pouring wine into a cup in a domestic context, or wine into a patera at a sanctuary. What is more, it has been demonstrated above that anatomical votives were always situationally meaningful and, even more significantly for the purposes of this chapter, it appears that objects used as votive offerings comfortably, and often intentionally, blurred purely functional expectations. Firstly, although terracotta mold-made anatomical votives may have been produced to be used only as offerings within ritual contexts, how they functioned always varied in relation to the nature of the petition (e.g. the healing of a foot condition, or the acknowledgement of a pilgrimage). Secondly, a host of objects were recruited from other contexts and repurposed within votive cult. According to Jessica Hughes (2017b), when used as an offering, the ultimate function of both types of object - which she terms "purpose-made" and "non-purpose-made" - was the same: to acknowledge the making or outcome of a vow, even though each offered the opportunity for different understandings or, in short, the creation of individualized religious knowledge. In her words, non-purpose-made votives "permanently entangled the different spheres in which religion was practiced" (Hughes 2017b, 198), something which her study shows was a consequence of their existence as material entities with multivalent potential, rather than their original function alone. A mold-made anatomical votive was deemed to be no more powerful than a bandage, a ring, or a crutch simply because it was made with a specific ritual purpose in mind. Indeed, Hughes (2017b, 199) suggests that in some circumstances the latter might have "embodied an intense, permanent entanglement between gift and giver" precisely because it was not originally intended to function in a dedicatory capacity. A new

10 Examples include Insoll 2004; Boivin 2008; Bennett 2010; Olsen 2010; Hodder 2012. 
materialist might argue that this was also a consequence of it moving from one assemblage into another, allowing different aspects of its affective qualities to come to the fore.

Putting restrictive concepts of function to one side makes it easier to foreground the potential significance of the non-representational qualities of votive hands. Indeed, Bjørnar Olsen (2010, 34) notes, in sympathy with the discussion above, that "studies of material culture have become increasingly focused on the mental and representational: material culture as metaphor, symbol, icon, message, and text - in short, as always something other than itself." He proposes that it is more "appropriate and necessary to pay less attention to things" 'meaning' in the ordinary sense - that is, the way they may function as part of a signifying system," and more attention to the significance of things "in themselves" (Olsen 2010, 172). Similarly, although he adopts a different approach, Ian Hodder echoes Merleau-Ponty when he asserts that humans and objects become entangled because "materials and objects have affordances that are continuous from context to context. These material possibilities (whether instantiated or not) create potentials and constraints" (Hodder 2012, 94). Although it can be argued that Hodder ultimately places too much emphasis on dependency, for both scholars attending to objects means incorporating into our interpretations a more nuanced understanding of their potential affordances - that is, their essential material or affective qualities. ${ }^{11}$ Whether inorganic (stone reliefs, ceramic vessels, bronze tripods), or organic (the human body, foodstuffs, sacrificial victims, garlands, sacred trees), material properties and, to some extent, affective qualities, remain more or less constant from culture to culture, and period to period. Fired clay feels like fired clay whether it is encountered in the early 21st century CE or the early 3rd century BCE, even if levels of familiarity with that sensory experience, and the impact that it has on understandings of the object and the context in which it is encountered, might vary as a consequence of prevailing cultural norms, or individual embodied memories and culturally conditioned sensoria. Modern individuals, for instance, might be less accustomed to the day-to-day tactile affordances of terracotta than they are with plastic, but each material still has the same physical effect on the human sensorium. In order to emphasize these qualities, and to avoid reducing objects only to the symbolic or representational purposes to which they are put by humans, Olsen has sought to draw attention to the "otherness" of objects by referring to them as "things" in their own right. Talking about things, rather than objects, differentiates the inherent material qualities of entities such as

11 On affordances more generally see Knappett 2004; 2005; n.3 above. 
terracotta votive hands, from those qualities that humans impose upon them (Olsen 2010, 156). It also makes it easier to adopt a non-hierarchical flat ontology in which human agency is not automatically privileged, one in which an assemblage of equal things might include material objects (e.g. a terracotta votive hand), the acting, sensing, and thinking human body, ideas (perhaps in this case concerning ritual activities) and symbols (the visual representation of a body part). All of these components of the assemblage contribute their own particular, independent qualities as things in their own right. In this way, reframing objects as things allows our understandings of them to become less anthropocentric, certainly less dependent upon the assumption that human agency must always dominate when humans and materials entangle. It suggests that we would do well not to let the physical and affective properties of terracotta votive hands slip through our grasp entirely.

One way to explore the implications of this for mid-Republican hand votives is to begin by identifying their potential individual qualities as things, and what those might offer to an assemblage that also featured the human sensorium. These qualities might include the tactile and haptic affordances of fired terracotta as material that is immediately cool to the touch (although not as cold as stone) but which also gradually warms, is dry and possibly also dusty or friable, relatively heavy, hard and unpliable, dense, smooth surfaced but rough edged. They might also include aural qualities, such as the hollow or muted clunking resonance produced when terracotta is knocked against another hard surface, but also its capacity to remain independently silent, not to mention other affordances such as its earthy scent (and taste), its range of colors (greys, browns, oranges, yellows, creams), and the fact that in this instance it took the shape of a human hand with extended fingers. As an object, then, the votive hand was clay formed by human agency to look like a hand, but as a thing it was sensed as substantively other, its own qualities signaling that it was very different from the hand of the living dedicator. Of course, it is not entirely clear exactly how dedicants interacted with votive hands as part of the performance of ritual activities, and therefore how these qualities came to affect the living body. Nevertheless, a certain amount can be surmised on the basis that it is known that these items, and others like them, were intentionally carried into a sanctuary or other sacred place by a dedicant, and that they were subsequently left behind as part of the practice outlined above whereby votives were offered in acknowledgement of the completion of a vow, or as a gesture of thanksgiving. In order to accomplish this the dedicant must have manipulated the offering in their own hand(s) at some point during their dedicatory activities, perhaps moving around the sanctuary with it, possibly continuing to grasp it during any prayer or spoken gesture that they made. It was then given to the deity, perhaps by being placed by those same 
hands in a chosen location, passed to a cult official, or in some instances possibly even intentionally broken. ${ }^{12}$ A votive hand might therefore be handled, smelled, and viewed in various ways, potentially being gripped with differing degrees of force, and possibly even presented balanced on an outstretched palm, a gesture that because of the model's weight would be felt in the muscles of the arm and upper body, as well as impacting upon balance and movement. ${ }^{13}$ Identifying the thingliness of a votive hand in terms of its qualities - that is, the range of ways in which it might affect the sensing body as part of these activities - provides a forceful reminder of its tangibility. The sheer physicality of its existence emerges as something that, as well as being thought about, might also be touched, smelled, tasted, heard, and seen by an ancient person performing such ritual activities. Moreover, as a thing in its own right, the votive hand was capable of affecting the living body by compelling it to feel and acknowledge particular things ("this is stiff and cool; it does not feel like clutching a living hand"), or move in certain ways ("its weight requires a firm grip"). Appreciating the material thingliness of a votive hand can therefore be achieved without having to mentally reduce it to its raw material alone, and without diminishing the potential semiotic significance of its particular form as representational of something other than itself, in this case a proxy for the real hand of the dedicant. Indeed, from this standpoint, a terracotta votive hand can be acknowledged to have affected the body on at least three different levels: as a material thing, as a representational thing (votive hand), as a thing that was simultaneously a material and representational proxy for a real hand (described here as a "hand").

\section{Votive hands as properties}

The concept introduced at the end of the last section, whereby the combination of the material and representational affective qualities of a thing means

\footnotetext{
12 One of three favissae (votive dumps) associated with the sanctuary of Juno at Gabii contained votive terracottas and ceramic vessels which appear to have been broken prior to deposition, although it is unclear whether they were broken immediately prior to this act of secondary deposition or at the moment of the original dedication (Favissa II, late 3rd-early 2nd century BCE: Almagro-Gorbea 1982, 264).

13 The outstretched palm is a familiar feature of figurines from across Italy: Scarpellini 2013. Whether there were other bodily gestures involved, such as raising the object in the air, kissing or anointing it, or whether some dedicants explored the object's texture or features more closely with their fingers as they held it, remains unknown.
} 
that it "acquire[s] a set of semiotic quotation marks," derives in part from Andrew Sofer's (2003, 31) study of stage properties (more conventionally called theater props). ${ }^{14}$ His work offers a useful way of exploring the multiple layers of a votive hand's thingliness. In common with the argument that religious knowledge is a product of the bodily performance of ritual activities and engagement with material things, Sofer (2003, vi) is concerned with the ways in which stage props are "more than just three-dimensional symbols; they are part of the material fabric of the play in performance. Enlivened by the actor's touch, charged by the playwright's dialogue, and quickened in the spectator's imagination, they take on a life of their own as they weave in and out of the stage." With a few minor amendments (in italics), these words might be recast for ancient cult contexts:

[votive offerings] are more than just three-dimensional symbols; they are part of the material fabric of the [ritual] in performance. Enlivened by the [dedicator's] touch, charged by the [dedicator's words and actions], and quickened in the [dedicator's] imagination, they take on a life of their own as they weave in and out of the [ritual].

These two contexts also share a performative dynamic: like the performance of a play, religious performances involve activities in which humans " $d o$ ritual with their bodies" (Naerebout 2015, 107, original emphasis), in conjunction with an assemblage of other things, including a narrative (or a set of ideas), and a setting composed of bodies, minds, and materials. Similarly, the performance of plays and ritual activities is always spatially and temporally specific, and whilst the core of both may conform to a pre-determined scheme, each remains subject to subtle variations as a consequence of situational dynamics within its assemblage, such as the presence of performers/ spectators with varying prior experience or different corporeal capacities, and the unique affective qualities of its material components. Through the bodily performance of discrete activities and movements, sensory and emotive experiences, and engagement with the materialness of a host of things, spatially and temporally specific place is also produced (Knott 2005; Biehl 2007; Graham (forthcoming)) or, put another way, ritual activities, like plays, also involve the creation of a "world within a world." Seen in these terms, a votive offering can be understood to play a role in the production of context-specific, or proximal religious knowledge in the same way that a

14 I am grateful to Helen Slaney for introducing me to the work of Sofer (2003) and Carlson (2001). Melissa Mueller (2016) has also recently pursued the topic of objects as actors within Greek tragedy, focusing on the spectator rather than the performer. 
stage prop produces and communicates its own context-specific knowledge. Both play an active part in the action of the performance, that is, by doing something in conjunction with the human body and mind in order to make a difference in the world. Votive offerings, like props in a play, were, after all, integral to progressing the action of votive cult activities since, as outlined above, it was their introduction into a sacred place, and the gesture of passing them over or otherwise rendering them sacred, that was crucial for the successful completion of the da ut dem ("give so that I may give") contract between mortal and deity (Graham and Draycott 2017, 7-8). Taking this further, however, it can be suggested that in order to produce these forms of context-specific knowledge, anatomical votives, again like stage props, relied upon the affective combination of their qualities as material things and their capacity to signify both hands in general and the very specific hand of the dedicator. It is here that their third level of thingliness - in this case as "hands" - emerges as significant.

Props and votives, such as anatomical models of hands, have the capacity to act as a proxy for something else, or in the words of Marvin Carlson (2001), to "ghost" other things (in this case, a real hand), as well as the histories or ideas associated with them (such as those outlined in Tab. 3). At the same time, as noted above, their individual qualities draw attention to their fundamental material otherness (Fig. 4). ${ }^{15}$ This capacity of things to ghost whilst simultaneously remaining tangible, is vital to both theater and ritual activities, since both involve circumstances which compel participants to temporarily understand the world as other than it normally is: the actor shot by a pistol does not actually die but the audience understands this to be the case within the constraints of that context; the votive dedicant knows that their model of a hand is not their own hand, but understands that in the context of their relationship with the divine it is a proxy for their hand. Props and votive offerings are things that, because of their combined semiotic and material qualities, sit between categories, with particular forms of situational knowledge arising out of the questions that they raise about the world. Can a stage pistol, even if it looks like a pistol, actually be a pistol if it cannot fire? Does a terracotta model of a hand remain merely a representation of a hand or can it become a "hand" in its own right? These questions compel us to return to the thingliness of objects, since props and votive offerings possess the potential to be

15 See Graham (2017a) for a study of how swaddled infant votives produce a similar sensory dissonance by looking like babies and compelling the body to move accordingly, at the same time as feeling, smelling, and sounding like terracotta models. For discussion of "ghosting" in ancient Greek theatrical contexts: Mueller 2016. 


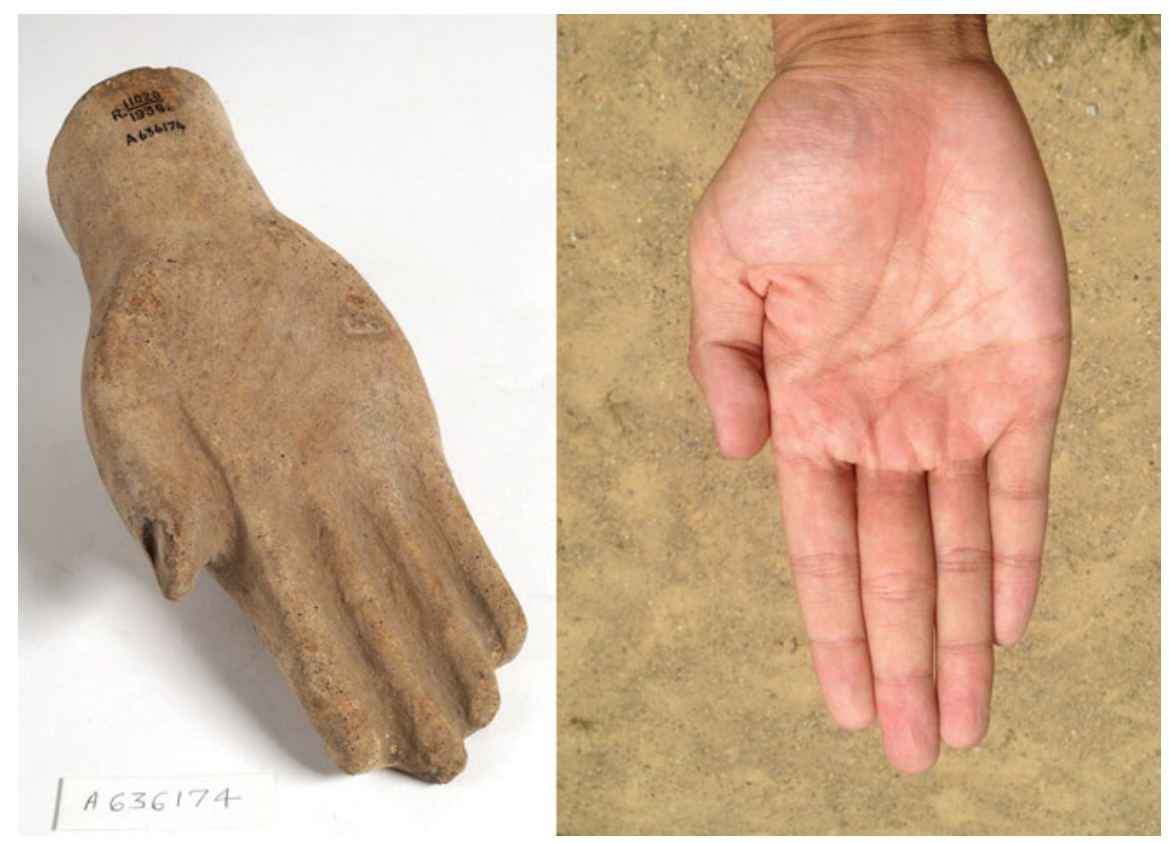

Fig. 4: A terracotta votive hand of unknown provenance (Wellcome Library, London, Museum No. A636174; reproduced under CC BY 4.0 License) as the "ghost" of a real hand (HNDPTESBC via Pixabay, reproduced under CCO 1.0 License).

more than they appear because of (a) what they physically are, (b) what they are made to do, and (c) what they make people do or understand as a result. An actor (and their audience) can be convinced, in that moment, that the table knife they wield is a dagger, because they are persuaded by what they make it do in the course of the action; they can also use it convincingly to do this because its material qualities and the way in which they affect their own bodily movements make it "feel like" a dagger. This would not be the case if it was replaced with, say, a fish or a pillow, because the qualities of those objects would compel them to do and feel different things. The manipulation of a terracotta hand in the course of dedicatory ritual activities might convince the bearer (and the deity who received it) that it represented a hand, even substituted for their own hand, because it looked like a hand. However, at the same time, its affective qualities, such as its weight, temperature, and lack of autonomous movement, forced the bearer to question this straightforward relationship. Consequently, their lived experience of the act of dedication drew attention to the out-of-the-ordinary possibilities of the world in which they 
currently dwelled as a dedicator, and on which their relationship with the divine was predicated.

\section{Conclusions: making sense of hands and "hands"}

How can conceptualizing votive offerings as akin to props, in combination with an appreciation of their thingliness as part of a relational assemblage, help to rematerialize understandings of the production of knowledge in ancient lived religion? The representational capacities of votive hands have been explored here alongside their existence as tangible material things in order to emphasize the extent to which both were crucial to the active role they played in the performance of ancient ritual activities. It has become evident that traditional approaches which focus exclusively on the former, despite the valuable emphasis they place on the offerings' multivalent potential, offer a limited view of the affectivity of votive offerings, emphasizing their role as signifiers rather than active participants in the assemblage of things that allowed a difference to be made to the world in the course of the performance of ritual activities. That is not to suggest that their signifying potential was unimportant, far from it. This quality was absolutely necessary in order for the dedicator, and the deity they petitioned, to establish a mutual understanding of what was represented by the offering that united them. Like stage props, they achieved this partly through their form what they resembled - and the ideas they had the capacity to signify or represent. Importantly, however, for the performer of ritual activities, the thingliness of the offering was also essential, because it was through physical interaction with it - as its qualities affected their sensing body in the course of a ritual performance - that they were made aware of its tangibility as more than a symbol, idea or metaphor. By grounding the experience in the material world, this produced, as noted above, "a confirmation that what one [was] experiencing [was] real, not just imaginary" (McGuire 2008, 102). At the same moment, the thingliness of the votive hand that the petitioner manipulated within their own hand, revealed itself to be fundamentally different from it. As a consequence, a votive hand presented itself in the recognizable form of a hand, but revealed itself to be something other than a real hand to the person who grasped it. ${ }^{16}$ From a new

16 For the role of props in creating a similar "reveal" of the fictionality of a theatrical scene in Greek tragedy see Mueller 2016, 127-128. 
materialist perspective, this demonstrates very well the need to emphasize "the way in which things and materials themselves bring elements to the table that go beyond what human beings think, know or understand about them" (Harris and Cipolla 2017, 146). Such an approach does not diminish the power of the votive hand as a signifier, or its capacity to represent an afflicted body part or something more ephemeral, such as the moment of manumission. Instead, it reveals that by compelling the dedicator to acknowledge the qualitative differences between their living hand, a model of a hand, and a proxy "hand" that was simultaneously both, the bodily sensory experience of the votive hand's thingliness could produce a complex yet compatible set of understandings that were appropriate for the distinctive "in between" context of votive activity and its associated locations "in which boundaries were transgressed" (Hughes 2017a, 103). More specifically, this suggests that, in part, the power of objects within ancient ritual performance may have rested in their potential, as things, to blur the boundaries of normal expectations and to allow all things - objects and bodies included - to be other than might be expected.

Moreover, it reveals something about how anatomical votive ritual activities were experienced and understood on a very personal or proximal bodily level. It also demonstrates how religious knowledge was consequently produced and lived in subtly different ways because of situational contexts connected not only with an individual's motive for a vow, but also with their proximal experiences of the qualities of the offering that they dedicated. Unlike other forms of offering, those acting as proxies for body parts were always obliged to become ghosts, since living body parts could not be detached and dedicated (except for hair and nails: Draycott 2017). This resulted in the production of an especially complex form of knowledge: the understanding that the clay model was not only a thing in its own right, and a representation of a hand, but that at that moment it was also the dedicant's own hand. It might even be suggested that in ritual activities associated with all anatomical votives, such as those described above, the very possibility that a model of a body part could exist simultaneously as both thing, hand and "hand", or thing, foot and "foot" was in fact crucial.

This chapter has suggested, then, a new way of approaching the anatomical votive offerings of mid-Republican Italy by emphasizing the thingliness of these offerings and their affective qualities. From this perspective it becomes possible to appreciate anatomical votives as much more than signifiers of medical conditions or moments in the life-course. Whilst the importance of the representational potential of anatomical votives, and their capacity to serve as material metaphors for immaterial concepts, has not been denied, these have been shown to be even more powerful when combined with a more 
explicit acknowledgement of the anatomical votive as merely one material thing within a wider assemblage of things that included the human body. The arguments about assemblages of equally relational things presented here, which might be applied to the material culture of ancient religion more broadly, have sought to turn attention back to the materialness of material culture, and in particular to stress the ways in which its very thingliness might be integral to the production of highly individualized forms of religious knowledge during the course of the performance of ritual activities, facilitating the "felt-life" of religion as it was lived on a personal scale.

\section{Bibliography}

Attenni, Luca 2017. 'Sacra Nemora.' In Sacra Nemora: La cultura del sacro nei contesti santuariali in area Albana, ed. Luca Attenni. Mozzecane. 28-29.

Attenni, Luca; Ghini, Giuseppina 2014. 'La stipe votiva in località Pantanacci (Genzano di Roma-Lanuvio, Roma)', Lazio e Sabina 10. 153-161.

Bailey, Doug 2014. 'Touch and the Cheirotic Apprehension of Prehistoric Figurines.' In Sculpture and Touch, ed. Peter Dent. Farnham. 27-44.

Bartoloni, Gilda; Benedettini, M. Gilda 2011. Veio. Il deposito votivo di Comunità (Scavi 1889-2005). Corpus delle Stipi Votive in Italia XXI, Regio VII, 3. Rome.

Bennett, Jane 2010. Vibrant Matter: A Political Ecology of Things. London.

Biehl, Peter F. 2007. 'Enclosing Places: A Contextual Approach to Cult and Religion in Neolithic Central Europe.' In Cult in Context: Reconsidering Ritual in Archaeology, ed. David. A. Barrowclough, Caroline Malone. Oxford. 173-182.

Boivin, Nicole 2008. Material Cultures, Material Minds: The Impact of Things on Human Thought, Society, and Evolution. Cambridge.

Boivin, Nicole 2009. 'Grasping the Elusive and Unknowable: Material Culture in Ritual Practice', Material Religion 5.3. 266-287.

Carlson, Marvin 2001. The Haunted Stage: The Theatre as Memory Machine. Ann Arbor.

Chidester, David 2005. 'The American Touch: Tactile Imagery in American Religion and Politics.' In The Book of Touch, ed. Constance Classen. Oxford. 49-65.

Comella, Annamaria 1981. 'Tipologia e diffusione dei complessi votivi in Italia in epoca medio- e tardo-repubblicana', Mélanges de l'École française de Rome, Antiquité 93. 717-803.

Comella, Annamaria 1982. Il deposito votivo presso l'Ara della Regina. Materiali del Museo Archeologico Nazionale di Tarquinia IV. Rome.

Cooper, Robert; Law, John 1995. 'Organisation: Distal and Proximal Views.' In Research in the Sociology of Organisations, ed. Samuel Bachrach, Pasquale Gagliardi, Bryan Mundell. Greenwich, CT. 237-274.

Crellin, Rachel J. 2017. 'Changing Assemblages: Vibrant Matter in Burial Assemblages', Cambridge Archaeological Journal 27.1. 111-125. 
Draycott, Jane 2017. 'Hair Today, Gone Tomorrow. The Use of Real, False and Artificial Hair as Votive Offerings.' In Bodies of Evidence: Ancient Anatomical Votives Past, Present and Future, ed. Jane Draycott, Emma-Jayne Graham. London. 77-94.

Draycott, Jane; Emma-Jayne Graham (eds.) 2017. Bodies of Evidence: Ancient Anatomical Votives Past, Present and Future. London.

Fenelli, Maria 1975. 'Contributo per lo studio del votivo anatomico: i votivi anatomici di Lavinio', Archeologia Classica 27. 206-252.

Ferrea, Laura; Pinna, Antonella 1986. 'Il deposito votivo.' In Fregellae 2. Il santuario di Esculapio, ed. Filippo Coarelli. Rome. 89-144.

Flemming, Rebecca 2017. 'Wombs for the Gods.' In Bodies of Evidence: Ancient Anatomical Votives Past, Present and Future, ed. Jane Draycott, Emma-Jayne Graham. London. 112-130.

Fowler, Chris 2017. 'Relational Typologies, Assemblage Theory and Early Bronze Age Burials', Cambridge Archaeological Journal 27. 95-19.

Frankfurter, David 2017. 'Ritual Matters: Afterword.' In Ritual Matters: Material Remains and Ancient Religion, ed. Claudia Moser, Jennifer Knust. Ann Arbor. 145-150.

Garcia-Rovira, Irene 2015. 'What About Us? On Archaeological Objects (or On the Objects of Archaeology)', Current Swedish Archaeology 23. 85-108.

Glinister, Fay 2006. 'Reconsidering “Religious Romanization”.' In Religion in Republican Italy, ed. Celia E. Schultz, Paul B. Harvey. Cambridge. 10-33.

Graham, Emma-Jayne 2017a. 'Babes in Arms? Sensory Dissonance and the Ambiguities of Votive Objects.' In Senses of the Empire: Multisensory Approaches to Roman Culture, ed. Eleanor Betts. London. 122-138.

Graham, Emma-Jayne 2017b. 'Mobility Impairment in the Sanctuaries of Early Roman Italy.' In Disability in Antiquity, ed. Christian Laes. London. 248-266.

Graham, Emma-Jayne (forthcoming). 'Mobility, kinaesthesia, Imagined Movement and the Making of Place in the Sanctuaries of Ancient Italy.' In Archaeology of Ritual in the Ancient Mediterranean: Recent Finds and Interpretative Approaches, ed. Erica Angliker, Michael A. Fowler. Liége.

Graham, Emma-Jayne; Draycott, Jane 2017. 'Debating the Anatomical Votive.' In Bodies of Evidence: Ancient Anatomical Votives Past, Present and Future, ed. Jane Draycott, Emma-Jayne Graham. London. 1-19.

Hamilakis, Yannis 2013. Archaeology and the Senses. Human Experience, Memory and Affect. Cambridge.

Hamilakis, Yannis; Meirion Jones, Andrew 2017. 'Archaeology and Assemblage', Cambridge Archaeological Journal 27. 77-84.

Harris, Oliver J.T.; Cipolla, Craig N. 2017. Archaeological Theory in the New Millennium: Introducing Current Perspectives. London.

Hodder, Ian 2012. Entangled: An Archaeology of the Relationships between Humans and Things. Malden, MA.

Hughes, Jessica 2008. 'Fragmentation as Metaphor in the Classical Healing Sanctuary', Social History of Medicine 21.2. 217-236.

Hughes, Jessica 2017a. Votive Body Parts in Greek and Roman Religion. Cambridge.

Hughes, Jessica 2017b. "“Souvenirs of the Self”: Personal Belongings as Votive Offerings in

Ancient Religion', Religion in the Roman Empire 3.2. 181-201.

Insoll, Timothy 2004. Archaeology, Ritual, Religion. London.

Ingold, Timothy 2007. 'Materials against Materiality', Archaeological Dialogues 14.1. 1-16. 
Ingold, Timothy 2012. 'Toward an Ecology of Materials', Annual Review of Anthropology 41. 427-442.

Joyce, Rosemary A. 2008. 'Practice In and As Deposition.' In Memory Work: Archaeologies of Material Practices, ed. Barbara J. Mills, William H. Walker. Santa Fe. 25-39.

Knappett, Carl 2004. 'The Affordances of Things: A Post-Gibsonian Perspective on the Relationality of Mind and Matter.' In Rethinking Materiality: The Engagement of Mind with the Material World, ed. Elizabeth DeMarrais, Chris Gosden, Colin Renfrew. Cambridge. 43-51.

Knappett, Carl 2005. Thinking Through Material Culture: An Interdisciplinary Perspective. Philadelphia.

Knott, Kim 2005. The Location of Religion: A Spatial Analysis. London.

Latour, Bruno 2005. Reassembling the Social: An Introduction to Actor-Network Theory. Oxford.

Malafouris, Lambros 2013. How Things Shape the Mind: A Theory of Material Engagement. Cambridge, MA.

McGuire, Meredith B. 2008. Lived Religion: Faith and Practice in Everyday Life. Oxford.

Merleau-Ponty, Maurice 1968. The Visible and the Invisible: Followed by Working Notes. Translated by Alphonso Lingis. Evanston.

Mills, Barbara J.; Walker, William H. 2008. 'Introduction: Memory, Materiality, and Depositional Practice.' In Memory Work: Archaeologies of Material Practices, ed. Barbara J. Mills, William H. Walker. Santa Fe. 3-23.

Morgan, David 2009. 'The Look of Sympathy: Religion, Visual Culture, and the Social Life of Feeling', Material Religion 5.2. 132-155.

Morgan, David 2010a. 'Introduction: The Matter of Belief.' In Religion and Material Culture: The Matter of Belief, ed. David Morgan. London. 1-17.

Morgan, David 2010b. 'The Material Culture of Lived Religion: Visuality and Embodiment.' In Mind and Matter, ed. Johanna Vakkari. Helsinki. 14-31.

Mueller, Melissa 2016. Objects as Actors: Props and the Poetics of Performance in Greek Tragedy. Chicago.

Naerebout, Frederick 2015. 'Dance.' In A Companion to the Archaeology of Religion in the Ancient World, ed. Rubina Raja, Jörg Rüpke. Malden, MA. 107-119.

Olsen, Bjørnar 2010. In Defense of Things: Archaeology and the Ontology of Objects. Plymouth.

Petridou, Georgia 2017. 'Demeter as an Ophthalmologist? Eye Votives and the Cult of Demeter and Kore.' In Bodies of Evidence: Ancient Anatomical Votives Past, Present and Future, ed. Jane Draycott, Emma-Jayne Graham. London. 95-111.

Pollard, Joshua 2008. 'Deposition and Material Agency in the Early Neolithic of Southern Britain.' In Memory Work: Archaeologies of Material Practices, ed. Barbara J. Mills, William. H. Walker. Santa Fe. 41-59.

Potter, Timothy W. 1989. Una stipe votiva da Ponte di Nona. Rome.

Raja, Rubina; Weiss, Lara 2016. 'The Significance of Objects: Considerations on Agency and Context', Religion in the Roman Empire 2.3. 297-306.

Recke, Matthias 2013. 'Science as Art: Etruscan Anatomical Votives.' In The Etruscan World, ed. Jean Macintosh Turfa. London. 1068-1085.

Rieger, Anna-Katharina 2016. 'Waste Matters: Life Cycle and Agency of Pottery Employed in Greco-Roman Sacred Spaces', Religion in the Roman Empire 2.3. 307-339. 
Scarpellini, Margherita Gilda 2013. 'The Tradition of Votive Bronzes in Etruria.' In The Etruscan World, ed. Jean Macintosh Turfa. London. 1026-1040.

Sofer, Andrew 2003. The Stage Life of Props. Ann Arbor.

Turfa, Jean Macintosh 1994. 'Anatomical Votives and Italian Medical Tradition.' In Murlo and the Etruscans: Art and Society in Ancient Etruria, ed. Richard D. De Puma, Jocelyn P. Small. Madison. 224-240. 
